\title{
Farmer Knowledge in Potato Virus Epidemiology and Control in Kenya
}

\author{
John Onditi ${ }^{1,2} \cdot$ Nancy $\mathrm{Ng}^{\prime}$ anga ${ }^{2}$.

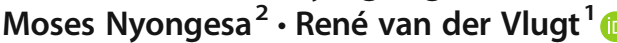

Received: 2 December 2019 / Accepted: 19 November 2020/ Published online: 18 December 2020

(C) The Author(s) 2020

\begin{abstract}
Potato is an important food security crop in Kenya. High prevalence of potato viruses is one of the major causes of low potato yields. Implementation of effective virus management strategies requires information on farmers' perceptions and practices on virus epidemiology and control. To better understand farmers' knowledge and practices in virus control and set possible pathways for intervention, a household survey involving 147 respondents was conducted in two major potato-growing regions in Kenya. Lack of sufficient technical information on potato virus symptoms, vectors and modes of transmission was found to be the major hindrance to farmers' efforts towards virus control. A spider diagram approach was therefore used to determine the aspect of virus control that required the highest prioritization for immediate intervention by policy makers. Use of virus-resistant cultivars was found to require the most urgent attention compared to other aspects of virus control and was expected to have greater impact in lowering virus prevalence. This study showed that enhancing farmer knowledge needs to be prioritised as this is a key determinant of the success of the virus control strategy to be selected for implementation.
\end{abstract}

Keywords Farmer knowledge · Potato $\cdot$ Virus control · Virus epidemiology

\section{Introduction}

Potato (Solanum tuberosum L.) is the second most important food crop in Kenya after maize (FAOSTAT 2017). The crop is considered a major staple food and an income

René van der Vlugt

rene.vandervlugt@wur.nl

1 Laboratory of Virology, Wageningen University and Research, Droevendaalsesteeg 1, 6708 PB Wageningen, The Netherlands

2 Kenya Agricultural and Livestock Research Organization, Horticultural Research Institute, KALRO Tigoni, P.O. Box 338, Limuru 00217, Kenya 
earner for rural households in the potato-producing regions, the majority of whom practise small-scale farming (Janssens et al. 2013). Potato is mainly cultivated in highaltitude areas (1500-3000 m above sea level), in regions around Mt. Kenya and in the highlands surrounding the Rift Valley (NPCK 2017). Despite the growing demand for potato and potato products across the Kenyan potato value chain (Janssens et al. 2013), potato yields are low with an average of $8.7 \mathrm{t} / \mathrm{ha}$ (FAOSTAT 2017) compared to a potential of over $35.0 \mathrm{t} / \mathrm{ha}$ under improved potato-growing conditions (Lung'aho et al. 2006; Onditi et al. 2012).

Potato viruses are among the major constraints to potato production in Kenya (Onditi et al. 2013). Six potato viruses, namely, Potato leaf roll virus (PLRV), Potato virus Y (PVY), Potato virus X (PVX), Potato virus M (PVM), Potato virus A (PVA) and Potato virus S (PVS) have been reported at high prevalence levels (Machangi 2003; Muthomi et al. 2009; Were et al. 2013). Once a mother plant is infected, the virus is transmitted to the next cropping generation through seed tubers (Khurana et al. 1998; Chandla et al. 2001; Rahman et al. 2010). This results in a build-up of virus infections after seasons of replanting virus-infected potato tubers leading to an increase in severity of virus infections and subsequent yield and crop quality losses over time (ThomasSharma et al. 2016). Potato crops infected with viruses are commonly found with symptoms such as leaf roll, leaf vein necrosis, leaf mosaic, tuber necrosis and stunted growth, each with varying levels of incidence and severity (Beemster and de Bokx 1987). Previous research in other regions in the world indicated that PLRV and PVY can cause yields losses of 80 to $100 \%$ while PVX, PVM, PVA and PVS typically cause mild mosaic symptoms resulting in yield losses of 10 to $20 \%$ (Salazar 1996).

Potato viruses can be controlled by avoiding farming practices that increase chances of virus transmission. Such practices include indiscriminate and active selection of smaller size tubers (which are often smaller due to virus infections) as planting materials for the subsequent seasons (Rahman et al. 2010); maintaining volunteer potato plants in or around the farm (Wright and Bishop 1981; Jones et al. 1996); cutting tubers prior to planting without following proper disinfection procedures; bruising seed tubers after harvest or mechanical injury to haulms during farm operations (Fageria et al. 2015); lack of a proper crop rotation/intercropping plan or overlap of potato-growing seasons in the same or neighbouring farms (Ragsdale et al. 2001) and maintaining alternative host plants of potato viruses in the field (Syller and Kaliciak 2009). Some of the potato virus control methods that have been proposed include the use of certified seed tubers or seed of a known clean source (Kabira et al. 2006; Almekinders et al. 2019), positive seed selection (Gildemacher et al. 2011; Schulte-Geldermann et al. 2012; Priegnitz et al. 2019), control of aphids (virus vectors) by use of various forms of pesticides (Olubayo et al. 2010), use of virus-resistant cultivars (Onditi et al. 2013) and use of border barrier crops to control aphids (Olubayo et al. 2010). Virus control using resistant cultivars which can withstand virus degeneration can be a long-term, cost-effective solution to potato virus problems in this region because over 95\% seed tubers planted in Kenya are not certified (Gildemacher et al. 2011; NPCK 2017) and farmers may have limited knowledge on virus control.

Development and implementation of an effective virus control strategy based on the cropping system is one of the ways in which yield losses associated with viruses can be reduced (Islam et al. 2017). Farmers' knowledge, perceptions and practices can be used in developing a package for control of various pest and diseases in developing countries and for improving their capacity to manage pests and diseases (Florin et al. 2012; 
Midega et al. 2016; Mendesil et al. 2016). This study was therefore conducted to identify gaps in farmers' perceptions and practices in relation to potato virus control and to suggest aspects of virus control in order of priority for implementation.

\section{Methodology}

\section{A Description of Survey Sites}

A farmer household survey was conducted in Nyandarua and Kiambu counties in Kenya. The two counties were selected because they are among the leading potatoproducing regions in the country and potato is central to their economic activities (Kaguongo et al. 2008). In addition, a recent virus survey (Onditi et al. 2016) showed differences in virus prevalence and cultivar choice between Nyandarua County and other counties. Nyandarua County was found to have the lowest virus prevalence and to have a unique preference for one potato cultivar (Shangi) while Kiambu County had a higher virus prevalence with a preference for different cultivars. These findings triggered an inquiry into cultural perceptions and farming practices that may influence potato virus epidemiology and control.

\section{Sampling Method, Data Collection and Analysis}

A representative sample of $147(N)$ respondents interviewed in the survey was calculated as previously described by Singh and Masuku (2014) as:

$$
N=\frac{Z^{2} \times p \times q}{e^{2}}
$$

where $Z^{2}$ is the normal variate (1.96), $p$ is an estimated proportion of measured attribute, $q$ is $(1-p)$, and $e$ is the desired precision $=0.05$.

Farms were identified using simple random sampling in August 2018 within the two counties. The person interviewed (farmer) within each farm was the one largely in charge and directly involved in day to day management of the farm activities. Randomization of the survey sites was done using the QGIS software (QGIS 2019) according to the total number of respondents to be interviewed. In cases where the GPS locations of the generated random points did not fall exactly into a potato farm or fell into a sub-region of the county where potato was not grown, the nearest potato farm to the random point was selected for the survey. Data were collected by administering a semi-structured questionnaire. Open-ended questions allowed respondents to express themselves fully allowing collection of as much information as possible. Answers were collected into open data kit (ODK 2018; www.opendatakit. org), an android (Google Inc.) smart phone application, while taking the GPS (global positioning system) position of the farms (Maduka et al. 2017). The GPS coordinates were used to generate the map showing the actual survey points using QGIS software (QGIS 2019) (Fig. 1). To describe the present status of farmer knowledge and practice in potato virus control, data obtained were analysed to obtain descriptive statistics in Microsoft Excel (2013). 


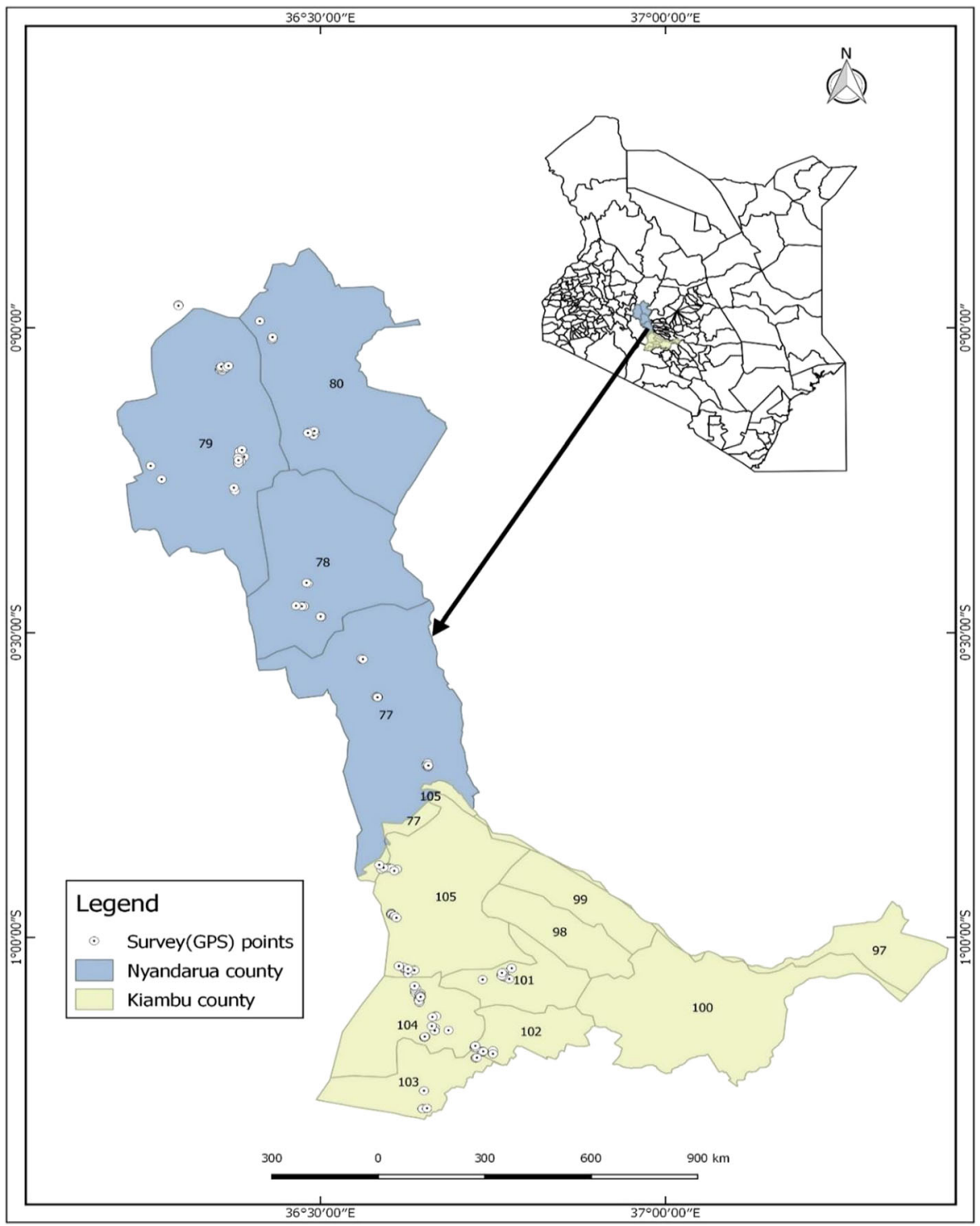

Fig. 1 Administrative map of Nyandarua and Kiambu counties with questionnaire survey points indicated

To set up a basis for decision making for potato virus control, a system approach using spider diagrams (De Olde et al. 2016) was adapted to the potato (virus) growing situation in Kenya. The first step was to set the overall goal, defined as the 'principal' (Florin et al. 2014) which for this case was to effectively control potato viruses in the Kenyan potato farming systems. To achieve the overall goal, there are set conditions or general rules that govern the outcome of the overall goal called the 'criteria' (Florin et al. 2014). For this case, the criteria for potato virus control were to: 
1. Improve farmer knowledge on reducing aphid (vector) virus transmission.

2. Improve farmer knowledge on reducing virus transmission through seed tubers.

3. Improve farmer knowledge on reducing mechanical or contact virus transmission.

4. Improve farmer knowledge on the sources of virus inoculum around the potato crop.

5. Improve farmer knowledge on the use of host resistance in virus control.

6. Improve farmer knowledge on effective use of pesticides in virus vector control.

The measurable parameters under each of the above criteria are called the 'indicators' (Florin et al. 2014). A conceptual framework of the relationship between principals, criteria and the indicators in relation to the Kenya potato virus situation is presented in Fig. 2. The indicator values were assigned based on the level of farmer knowledge and practice in potato virus epidemiology and control, as obtained from the farmer household survey, and are represented on a scale of $0-10$ (Marinus et al. 2018). For example, if $20 \%$ of respondents know about vector transmission of potato viruses, a value of 2 out of 10 was assigned.

Since indicators under each criterion in an agricultural system may have different weights based on the relative potential impact on overall sustainability of a system (Struik et al. 2014), indicators were assigned different weights in a matrix of 0-1 under each criterion (Marinus et al. 2018). All the indicator values under each criterion added up to 1. Expert opinion on the relative weight of each indicator in the Kenyan potato farming systems was used to assign the indicator weights (Table 5). Expert opinions were sourced from a panel of four potato scientists with specialty and experience in potato virus epidemiology and control under the local (Kenyan) potato-growing conditions and comprised a pathologist, a breeder, a socio-economist and a virologist. Expert opinion scores on various indicators of virus control were based on a consensus after deliberations on their personal experiences in potato research in Kenya and also on the available literature determined by the relative impact of each of the indicators on potato virus epidemiology and control and in relation to the potato-producing situation in the country.

Criteria values (Table 5) were calculated as the total sum of the product of the individual indicator values and their respective indicator weights. For instance, if there were three indicators with values of $2.4,4.0$ and 0.5 and each with equal indicator weights of 0.33 , the criteria values were calculated as $(2.4 \times 0.33)+(4.0 \times 0.33)+$ $(0.5 \times 0.33)=2.3$ as proposed by Marinus et al. 2018 . The criteria values ranged from 0 to 10 where ' 0 ' depicts an aspect of virus control that requires the highest priority in implementation while 10 , the least priority. The values were visualised in spider

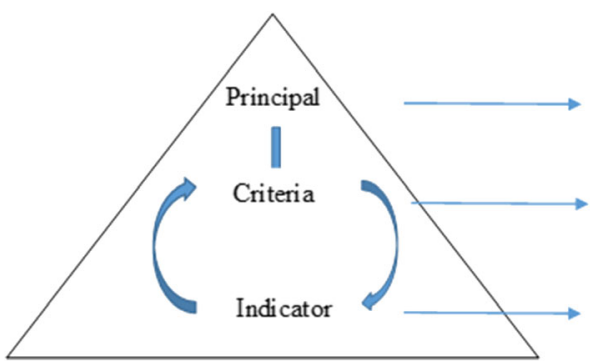

\author{
Effective control potato viruses in \\ the Kenyan potato farming systems \\ Conditions that have to be met for \\ effective virus control \\ Specific aspects of virus \\ management e.g. $\%$ of farmers \\ spraying against aphids
}

Fig. 2 An illustration of the casual relationship between principal, criteria and indicator (Florin et al. 2014) in relation to potato virus epidemiology and control situation in Kenya 
diagrams (Figs 5 and 6) using Microsoft Excel. A value of zero in the spider diagram represented a situation which required more urgent intervention compared to a value of ten which indicated that viruses were perfectly controlled, and farmers did not need any support in virus control.

\section{Results}

\section{A General Description of Survey Sites}

Average farm sizes in Kiambu and Nyandarua regions in Kenya were small (1.0 ha) and typical of a small-scale farming system. Respondents in both counties used $70 \%$ $(0.7 \mathrm{ha})$ of their total farm area for growing crops. Potato was planted in $35.7 \%$ ( $0.25 \mathrm{ha})$ of the total area under crops $(28.6 \%$ in Kiambu and $42.8 \%$ in Nyandarua). There was a higher number of male respondents in Nyandarua $(53.2 \%)$ and a higher number of female respondents in Kiambu $(67.1 \%)$.

\section{A Description of Farmers' Knowledge and Practice in Potato Virus Control}

\section{Farmers' Knowledge of Virus Symptoms and Vector Virus Transmission}

To understand farmers' knowledge of virus symptoms and vector transmission of potato viruses, respondents were shown images of aphids on the underside of potato leaves and images of common potato virus symptoms (mosaic, stunted growth, necrosis, chlorosis and leaf roll). They were asked to name the insect vector/pest and the plant disease characterised by the symptoms in the images respectively. Only $36.1 \%$ of the respondents were able to identify aphids correctly with $40.0 \%$ in Kiambu and $32.2 \%$ in Nyandarua. Similarly, only a few respondents $(18.2 \%)$ were able to correctly identify potato virus symptoms (23.5\% in Kiambu and $12.9 \%$ in Nyandarua). Farmers' understanding of the role of aphids in virus transmission was very poor (Table 1). A clear majority of respondents $(94.5 \%)$ who did not identify aphids correctly also did not identify the correct virus symptoms $(86.5 \%$ in Kiambu and $97.6 \%$ in Nyandarua). Regarding the role of aphids in potato virus transmission, only 8.0\% (4.7\% in Kiambu and $11.3 \%$ in Nyandarua) of farmers associated aphids with potato virus transmission while the rest associated aphids with other constraints of potato production.

\section{Use of Insecticides to Control Aphids}

To understand the level of farmer knowledge in pesticide use for effective potato virus vector control, farmers were asked about their knowledge and practices in pesticide application. Almost half the farmers (44.9\%) applied pesticides (including insecticides to control aphids) on their potato crop (41.2\% in Kiambu and $48.6 \%$ in Nyandarua). Farmers' responses on why they did not apply pesticides are summarised in Table 1. Farmers' lack of necessary information required for effective vector control using pesticides was the main reason they did not apply pesticides. Only $23.0 \%$ of the farmers $(28.0 \%$ in Kiambu and $18.0 \%$ in Nyandarua) were found to have the knowledge required for effective application of pesticides. Respondents were asked if they 
Table 1 Description of farmers' knowledge and practice in potato virus transmission and vector control

\begin{tabular}{|c|c|c|c|c|}
\hline \multirow[t]{2}{*}{ Question } & \multirow[t]{2}{*}{ Farmer response(s)/practice(s) } & \multicolumn{3}{|c|}{ Percentage of farmers $(\%)$} \\
\hline & & Kiambu & Nyandarua & Mean \\
\hline \multirow{8}{*}{$\begin{array}{l}\text { Farmers' knowledge of the role of } \\
\text { aphids in potato virus } \\
\text { transmission }\end{array}$} & Farmer does not know & 68.2 & 72.6 & 70.4 \\
\hline & Transmit potato viruses & 4.7 & 11.3 & 8.0 \\
\hline & Suck plant sap & 0.0 & 11.3 & 5.6 \\
\hline & Lower yields & 7.1 & 3.2 & 5.1 \\
\hline & Wilting of leaves & 9.4 & 0.0 & 4.7 \\
\hline & Farmer sees no effect on the crop & 3.5 & 1.6 & 2.6 \\
\hline & Cause late blight & 3.5 & 0.0 & 1.8 \\
\hline & Feed on the leaves & 3.5 & 0.0 & 1.8 \\
\hline \multirow{6}{*}{$\begin{array}{l}\text { Why farmers do not apply pesticides } \\
\text { on their crop }\end{array}$} & Aphids have no effect on the potato crop & 41.2 & 2.6 & 21.9 \\
\hline & Lack of technical information & 29.4 & 24.4 & 26.9 \\
\hline & No reason & 15.7 & 24.4 & 20.1 \\
\hline & Not available & 7.8 & 48.5 & 28.2 \\
\hline & Not effective & 3.9 & 0.0 & 2.0 \\
\hline & Too costly & 2.0 & 0.0 & 1.0 \\
\hline
\end{tabular}

scouted for pests and diseases in their crop and almost half of them (49.3\%) did so (47.1\% in Kiambu and $51.6 \%$ in Nyandarua). Among farmers who scouted for pests and diseases, only a small fraction $(20.5 \%)$ checked specifically for aphids and viruses (28.2\% in Kiambu and $12.9 \%$ in Nyandarua) on their potato crops. Farmers who scouted for aphids in their crops did so at an average of 18-day intervals (16-day intervals in Kiambu and 20-day intervals in Nyandarua counties, respectively).

\section{Use of Host Resistance to Control Potato Viruses and Improve Potato Yields}

Table 2 lists the most important potato cultivars grown in the two counties. Among all the farms visited in both counties, Shangi was the most popularly grown (90.5\%) and was the only cultivar in Nyandarua County. Even though farmers in Kiambu grew 11 different cultivars, Shangi was still their main (83.5\%) potato cultivar. Area under potato (ha) and the yields (t) as reported during the survey interview over the cropping season of long rains 2018 (April to August 2018) were used to calculate average potato yield of the cultivars grown (Table 2). The overall average potato yields as reported by farmers interviewed in the two counties were very low $(5.1 \mathrm{t} / \mathrm{ha})$. The most popular cultivar (Shangi) was also the high yielding. The highest yields $(7.3 \mathrm{t} / \mathrm{ha})$ were realised in Nyandarua County, where all the respondents grew cultivar Shangi. In Kiambu where respondents grew 11 different cultivars, the yields were lower (0.9-6.9 t/ha). To understand if farmers considered potato virus tolerance an important factor during cultivar choice and selection, they were asked about the important characteristics that they preferred in the potato cultivars they grew (Table 3). Tolerance to viruses was among the traits which attracted the least attention $(1.0 \%)$ during potato cultivar selection with only $2.0 \%$ in Kiambu and $0.0 \%$ in Nyandarua. Instead, the most 
Table 2 Cultivars grown and average (mean) potato yield (t/ha) among potato farmers in Kiambu and Nyandarua counties

\begin{tabular}{|c|c|c|c|c|c|c|}
\hline \multirow[t]{2}{*}{ Cultivar name } & \multicolumn{3}{|c|}{ Percentage of farmers growing the cultivar (\%) } & \multicolumn{3}{|c|}{ Average yield (t/ha) } \\
\hline & Kiambu & Nyandarua & Mean & Kiambu & Nyandarua & Mean \\
\hline Shangi & 83.5 & 100 & 90.5 & 2.8 & 7.3 & 5.1 \\
\hline Unica & 1.2 & Not grown & - & 6.9 & Not grown & - \\
\hline Tigoni & 3.5 & Not grown & - & 5.9 & Not grown & - \\
\hline Kenya Karibu & 3.5 & Not grown & - & 5.1 & Not grown & - \\
\hline Nyayo & 2.4 & Not grown & - & 3.1 & Not grown & - \\
\hline Thimathuti & 1.2 & Not grown & - & 1.8 & Not grown & - \\
\hline Kagosi & 1.2 & Not grown & - & 1.6 & Not grown & - \\
\hline Kerr's Pink & 1.2 & Not grown & - & 1.5 & Not grown & - \\
\hline Ndera Mwana & 7.1 & Not grown & - & 1.4 & Not grown & - \\
\hline Desiree & 2.4 & Not grown & - & 1.3 & Not grown & - \\
\hline \multirow[t]{2}{*}{ Kalucy } & 3.5 & Not grown & - & 0.9 & Not grown & \\
\hline & & & & 2.9 & 7.3 & 5.1 \\
\hline
\end{tabular}

preferred characteristics included high yields (46.0\%), large-sized tubers (14.4\%), high market demand $(9.4 \%)$, good mix of large- and medium-sized tubers $(8.5 \%)$ and early maturity $(7.9 \%)$.

\section{Virus Transmission Through Seed Tubers}

Farmers' knowledge on virus transmission through seed tubers was limited. Only $22.6 \%$ of the respondents (27.4\% in Kiambu and $17.7 \%$ in Nyandarua) were found to be aware that re-using their own (non-certified) virus infected seed tubers is one of the major pathways of virus transmission into their potato crops. In addition, very few $(21.0 \%)$ farmers had in the past replaced seed tubers of their potato crop (27.4\% and $14.5 \%$ in Kiambu and Nyandarua, respectively) with a newer and healthier seed source. The few farmers who replaced their seed tubers did so after an average of 4.5 years or approximately 9 cropping seasons (4.9 and 4.1 years in Kiambu and Nyandarua, respectively). Few farmers (10.2\% with $19.0 \%$ in Kiambu and $1.4 \%$ in Nyandarua) planted certified seed potato either from KALRO or other formal certified seed producers. Most farmers planted ware potatoes bought from local markets $(45.2 \%$ with $41.9 \%$ in Kiambu and $48.6 \%$ in Nyandarua) and others from neighbours (38.8\% with $27.6 \%$ in Kiambu and $50.0 \%$ in Nyandarua) and from own saved seed $(5.7 \%$ with $11.4 \%$ in Kiambu and $0.0 \%$ in Nyandarua).

\section{Mechanical Transmission of Potato Viruses}

A clear majority of the farmers interviewed (99.5\% with $98.9 \%$ in Kiambu and $100.0 \%$ in Nyandarua) were aware that cutting seed tubers can spread diseases in potato. As a result, a vast majority of farmers $(98.1 \%$ with $97.8 \%$ in Kiambu and $98.5 \%$ in Nyandarua) were found not to be cutting seed tubers before planting. In addition, a 
Table 3 Percentage of farmers (\%) with preference to various characteristics in potato cultivars grown in Kiambu and Nyandarua counties

\begin{tabular}{|c|c|c|c|}
\hline \multirow[t]{2}{*}{ Farmer response(s)/practice(s) } & \multicolumn{3}{|c|}{ Percentage of farmers $(\%)$} \\
\hline & Kiambu & Nyandarua & Mean \\
\hline High yields & 44.3 & 47.7 & 46.0 \\
\hline Big (large sized) tubers & 16.1 & 12.6 & 14.4 \\
\hline High market demand & 5.4 & 13.5 & 9.4 \\
\hline Good mix of large- and medium-sized tubers & 13.4 & 3.6 & 8.5 \\
\hline Early maturity & 4.0 & 11.7 & 7.9 \\
\hline Well adapted to local growing conditions & 0.0 & 5.4 & 2.7 \\
\hline Lack of better alternative cultivars & 2.7 & 2.7 & 2.7 \\
\hline Good taste & 5.4 & 0.0 & 2.7 \\
\hline Late blight tolerance & 3.4 & 0.0 & 1.7 \\
\hline Bacterial wilt tolerance & 2.0 & 0.0 & 1.0 \\
\hline Virus tolerance & 2.0 & 0.0 & 1.0 \\
\hline Medium-sized tubers & 1.3 & 0.0 & 0.7 \\
\hline Availability of seed & 0.0 & 0.9 & 0.5 \\
\hline Drought tolerance & 0.0 & 0.9 & 0.5 \\
\hline Short dormancy & 0.0 & 0.9 & 0.5 \\
\hline
\end{tabular}

majority of farmers considered it unprofitable $(99.5 \%$ with $98.9 \%$ in Kiambu and $100.0 \%$ in Nyandarua) to cut seed tubers. A majority of farmers $(69.9 \%$ with $67.0 \%$ in Kiambu and $71.8 \%$ in Nyandarua) also did not cut the haulms of their potato crop shortly before harvesting. Among those that cut the haulms, only a few $(4.4 \%$ with $8.8 \%$ in Kiambu and $0.0 \%$ in Nyandarua) used sharp objects that could transmit potato viruses. Instead they uprooted plants gently, leaving the tubers in the soil. After dehaulming, farmers did not take too long before harvesting. Farmers took an average of 9 days (12 days in Kiambu and 6 days in Nyandarua) from dehaulming to harvesting.

\section{Role of Alternative Host Plants and Other Sources of Virus Inoculum in Virus Transmission}

\section{Crop and Weed Species Acting as Alternative Host Plants for Potato Viruses}

Nine plant species which are potential alternative hosts for potato viruses from the family Solanaceae were found in or around $19.7 \%$ of potato farms with $16.7 \%$ in Kiambu and $22.7 \%$ in Nyandarua (Table 4). Farmers were asked a question to find out if they were understanding the fact that alternative host plants of potato viruses around their farms could act as source of inoculum for virus transmission to their crops. Only 7.5\% of farmers with $10.0 \%$ in Kiambu and $5.0 \%$ in Nyandarua had that kind of knowledge. Sodom apple (Solanum incanum) (43.0\%), Datura spp. (39.9\%) and Black night shade (Solanum nigrum) (32.2\%) were found more frequently while pepper (Capsicum annuum) (0.6\%) and angels trumpet (Brugmansia spp.) (1.0\%) were least common. Farmers were asked the duration of vegetative growth in each of the above 
Table 4 Prevalence and duration of alternative host plants of potato viruses in farmers' fields in Nyandarua and Kiambu counties of Kenya and levels of farmer knowledge of their potential risk as source of inoculum for potato virus transmission

\begin{tabular}{|c|c|c|c|c|c|c|c|c|c|}
\hline \multirow[t]{2}{*}{$\begin{array}{l}\text { Solanaceous } \\
\text { crop/weed* }^{*}\end{array}$} & \multicolumn{3}{|c|}{$\begin{array}{l}\% \text { of farmers with each of } \\
\text { the listed plants in/around } \\
\text { their potato farms** }\end{array}$} & \multicolumn{3}{|c|}{$\begin{array}{l}\text { Average duration of the } \\
\text { plants in/around potato } \\
\text { farms (months) } \text { * }^{* *}\end{array}$} & \multicolumn{3}{|c|}{$\begin{array}{l}\% \text { of farmers knowing the } \\
\text { plants are a source of virus } \\
\text { that can be transmitted to } \\
\text { their potato crops }\end{array}$} \\
\hline & Kiambu & Nyandarua & Mean & Kiambu & Nyandarua & Mean & Kiambu & Nyandarua & Mean \\
\hline S. incanum & 11.9 & 31.1 & 21.5 & 9.4 & 7.5 & 8.5 & 25.0 & 4.5 & 14.8 \\
\hline Datura spp. & 26.7 & 5.5 & 16.1 & 3.0 & 6.3 & 4.6 & 22.8 & 25 & 23.9 \\
\hline S. nigrum & 32.9 & 30.6 & 31.8 & 3.4 & 3.4 & 3.4 & 28.6 & 5.5 & 17.1 \\
\hline S. muricatum & 11.8 & 32.3 & 22.0 & 7.4 & 5.8 & 6.6 & 10.0 & 5.0 & 7.5 \\
\hline S. betaceum & 10.6 & 12.9 & 11.7 & 8.8 & 11.4 & 10.1 & 33.3 & 0.0 & 16.7 \\
\hline S. lycopersicun & 17.6 & 1.6 & 9.6 & 3.8 & 3.0 & 3.4 & 26.7 & 0.0 & 13.4 \\
\hline Physalis spp. & 7.1 & 3.2 & 5.1 & 6.0 & 0.8 & 3.4 & 0.0 & 5.0 & 2.5 \\
\hline Brugmansia spp. & 2.0 & 0.0 & 1.0 & 2.0 & 2.0 & 2.0 & 0.0 & 0.0 & 0.0 \\
\hline C. апnиит & 1.2 & 0.0 & 0.6 & 3.0 & 3.0 & 3.0 & 0.0 & 0.0 & 0.0 \\
\hline
\end{tabular}

*Some of the Solanaceous plants were both crops and weeds at the same time except S. nigrum, S. lycopersicum, Physalis spp. and Capsicum annuиm. **Scored by scouting through the farm for the presence of each of the plants in each of the surveyed farms. The percentages show the prevalence of the plants among all the surveyed farms. ***Scored by asking the farmers the month of emergence and the month of senescence and this was used to calculate averages shown for each plant species

crops in their farms. The average duration of three Solanaceous plants (Sodom apple, Datura spp. and Black night shade) were found to be long enough (10.1, 8.5 and 6.6 months, respectively) to overlap two potato-growing seasons of the year and act as potential sources of virus inoculum for transmission from one season to another.

\section{Crop Rotation and Intercropping in Considering Alternative Host Plants of Viruses}

Although intercropping (37.0\% with $42.4 \%$ in Kiambu and $31.7 \%$ in Nyandarua) and crop rotation $(86.0 \%$ with $81.2 \%$ in Kiambu and $90.8 \%$ in Nyandarua) were commonly practised by farmers, only $5.7 \%$ (with $7.1 \%$ in Kiambu and $4.7 \%$ in Nyandarua) intercropped or rotated their potato crop with Solanaceous plants which would have acted as potential sources of virus inoculum to their crop.

\section{Control and Management of Volunteer Potato Plants}

A large proportion of farmers (79.8\%) had volunteer potato plants in their fields. Over half of them $(57.7 \%)$ deliberately left tubers in the field at harvest to produce a bridging crop that many farmers $(41.5 \%)$ were tending by weeding and controlling pests and diseases. Tubers harvested from the volunteer crop provided food early in the season before the main potato crop matured in most farms (52\%) and this was the main reason why the practice was common among the farmers and was difficult to eradicate. Farmer knowledge that keeping volunteer potatoes in the farm can maintain and spread viral and other 
seed-borne diseases was largely limited $(6.4 \%)$ with $5.0 \%$ in Kiambu and $7.8 \%$ in Nyandarua. Many farmers $(78.0 \%)$ did not know of any disadvantages of having volunteer potatoes while only a few $(15.6 \%)$ considered them as weeds in the farm.

\section{Overlap of Potato-Growing Seasons and Potato Virus Transmission}

To understand if the duration of the two potato-cropping seasons overlaps in the field in a year (a situation that can lead to transmission of viral diseases from one season to another), farmers were asked the months of the year when they planted and harvested their crop (Figs. 3 and 4) and this was used to establish the duration of potato crops in the field. Potato crops in the field overlapped all through the year both in Kiambu and Nyandarua counties. Farmers planted potatoes in almost all the months of the year. When the farmers were asked how many times in a year they planted potatoes, most farmers $(78.0 \%)$ grew potatoes twice a year $(88.2 \%$ in Kiambu and $67.7 \%$ in Nyandarua) and another $15.6 \%$ planted them three times a year $(7.1 \%$ in Kiambu and $24.2 \%$ in Nyandarua). Very few farmers (6.4\%) with only $4.7 \%$ in Kiambu and $8.1 \%$ Nyandarua planted potatoes only once a year.

\section{Analysis of Order of Priority in Intervention in Potato Virus Control Using Spider Diagrams}

The criteria values and the indicators of potato virus control by farmers in Kiambu and Nyandarua counties in Kenya are summarised in Table 5. The individual indicators

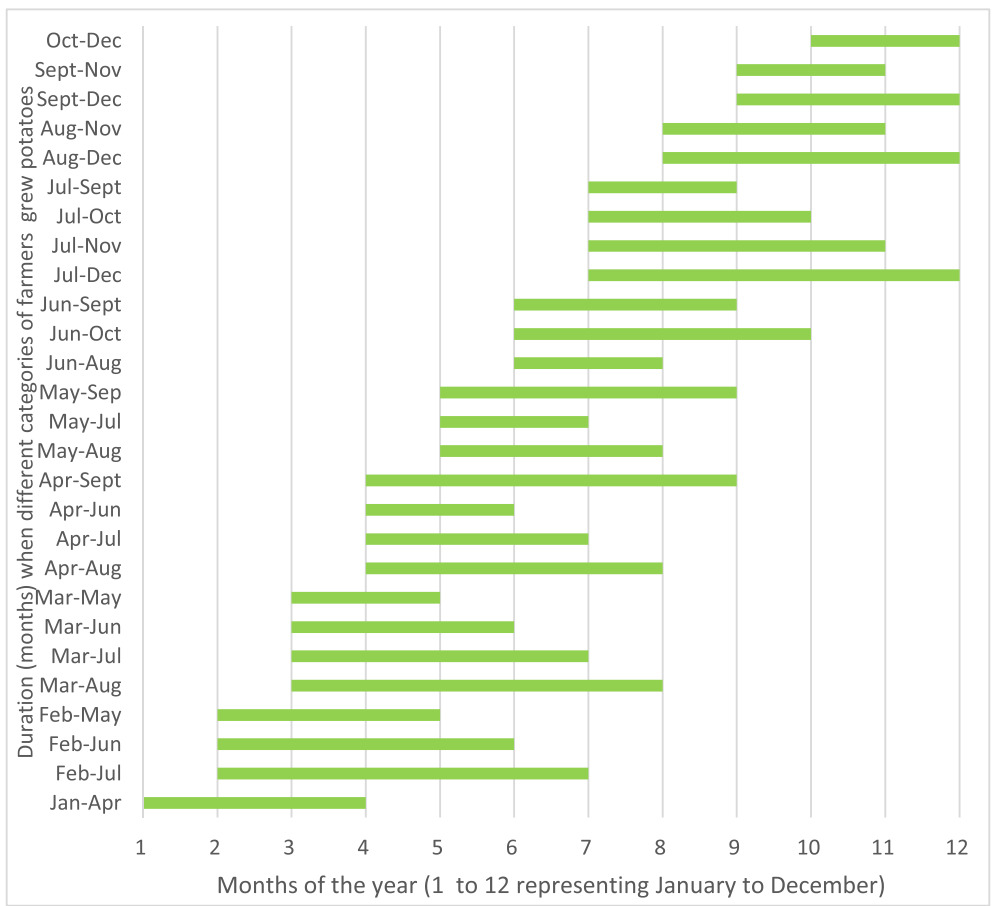

Fig. 3 Overlap of potato-growing periods in Kiambu County, Kenya, in the year prior to the survey (2017) 


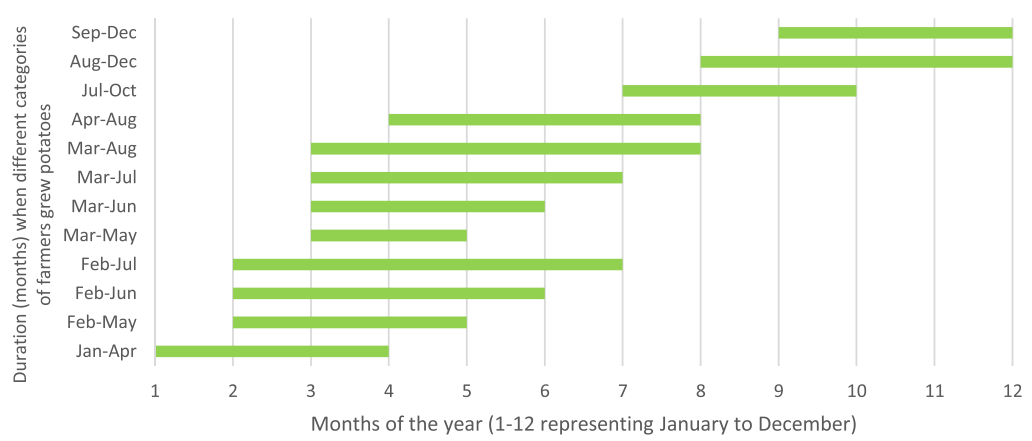

Fig. 4 Overlap of potato-growing periods in Nyandarua County, Kenya, in the year prior to the survey (2017)

linked to each of the six criteria were listed with their corresponding indicator weights. These were assigned based on the outcomes of the farmer surveys and on the experts' judgements of the relative impact of the indicators on potato virus epidemiology and control. The final criteria values calculated as the sum of the product of the indicators and their respective weights under each criterion are presented visually in the form of a spider diagram in Fig. 5. The criteria values are the broader aspects of potato virus epidemiology and control that need to be taken into consideration to effectively manage the potato virus problem in the two counties. The lowest value ' 0 ' represents an aspect which requires a lot of attention and ' 10 ' represents a perfect situation where no further improvements are needed. The indicator values in Table 5 depict the present levels of farmer knowledge in potato virus epidemiology and control for every county and are also visually presented in the form of spider diagram in Fig. 6.

From the analysis, we ranked the various aspects of virus control based on their order of priority (Table 5). In Kiambu county, the order of priority in virus control based on the respective criteria values in the spider diagram starting with the one that requires highest priority was:

1. Using host resistance in virus control (0.2).

2. Avoiding sources of virus inoculum (1.2).

3. Avoiding vector transmission of viruses (2.3).

4. Avoiding virus transmission through seed tubers (2.5).

5. Knowledge of effective use of pesticides in virus vector control (3.4).

6. Avoiding mechanical transmission of viruses (9.2).

In Nyandarua county, the scores and the order of priority were ranked as follows:

1. Using host resistance in virus control (0.0).

2. Avoiding sources of virus inoculum (0.9).

3. Avoiding vector transmission of viruses (1.9).

4. Avoiding virus transmission through seed tubers (2.5).

5. Knowledge of effective use of pesticides in virus vector control (3.4).

6. Avoiding mechanical transmission of viruses (9.4). 
Table 5 Details of the six criteria (in italics) and their underlying indicators of potato virus control by farmers in Kiambu and Nyandarua counties of Kenya

\begin{tabular}{|c|c|c|c|c|c|}
\hline \multirow[t]{2}{*}{ Criteria and indicators of virus control ${ }^{*}$} & \multicolumn{2}{|c|}{ Indicator values $^{* *}$} & \multirow{2}{*}{$\begin{array}{l}\text { Indicator } \\
\text { weights }^{* * *}\end{array}$} & \multicolumn{2}{|c|}{ Criterion value ${ }^{* * * * *}$} \\
\hline & Kiambu & Nyandarua & & Kiambu & Nyandarua \\
\hline Vector transmission of viruses & & & & 2.3 & 1.9 \\
\hline $\begin{array}{l}\text { Proportion of farmers with knowledge to identify virus } \\
\text { symptoms }\end{array}$ & 2.4 & 1.3 & 0.33 & & \\
\hline $\begin{array}{l}\text { Proportion of farmers with knowledge to identify aphids } \\
\text { correctly }\end{array}$ & 4.0 & 3.2 & 0.33 & & \\
\hline $\begin{array}{l}\text { Proportion of farmers with knowledge of role of aphids in } \\
\text { virus transmission }\end{array}$ & 0.5 & 1.1 & 0.33 & & \\
\hline Using pesticides in virus vector control & & & & 3.4 & 2.7 \\
\hline $\begin{array}{l}\text { Proportion of farmers with correct knowledge on pesticide } \\
\text { application }\end{array}$ & 2.9 & 1.8 & 0.67 & & \\
\hline Proportion of farmers who control aphids using pesticides & 4.1 & 4.9 & 0.17 & & \\
\hline $\begin{array}{l}\text { Proportion of farmers who monitor for aphids on their } \\
\text { potato crop }\end{array}$ & 4.7 & 4.2 & 0.17 & & \\
\hline Virus transmission through seed tubers & & & & 2.5 & 1.7 \\
\hline $\begin{array}{l}\text { Proportion of farmers who ever replaced seed tubers of } \\
\text { degenerated crop }\end{array}$ & 2.7 & 1.5 & 0.20 & & \\
\hline $\begin{array}{l}\text { Proportion of farmers with knowledge of seed tuber virus } \\
\text { transmission }\end{array}$ & 2.7 & 1.8 & 0.60 & & \\
\hline Proportion of farmers who plant certified seed tubers & 1.9 & 1.4 & 0.20 & & \\
\hline Mechanical transmission of viruses & & & & 9.2 & 9.4 \\
\hline $\begin{array}{l}\text { Proportion of farmers with knowledge of mechanical } \\
\text { transmission of viruses }\end{array}$ & 9.9 & 10.0 & 0.60 & & \\
\hline $\begin{array}{l}\text { Proportion of farmers not cutting potato haulms before } \\
\text { harvesting }\end{array}$ & 9.8 & 9.9 & 0.20 & & \\
\hline Proportion of farmers not cutting seed tubers before planting & 6.7 & 7.2 & 0.20 & & \\
\hline Avoiding sources of virus inoculum & & & & 1.3 & 1.1 \\
\hline $\begin{array}{l}\text { Proportion of farmers with knowledge of alternative host } \\
\text { plants in potato viruses }\end{array}$ & 1.0 & 0.5 & 0.35 & & \\
\hline $\begin{array}{l}\text { Proportion of farmers without alternative host plants of } \\
\text { viruses in or around potato farms }\end{array}$ & 1.7 & 2.3 & 0.05 & & \\
\hline $\begin{array}{l}\text { Proportion of farmers without volunteer potatoes in or } \\
\text { around potato farms }\end{array}$ & 2.6 & 1.5 & 0.25 & & \\
\hline $\begin{array}{l}\text { Proportion of farmers with knowledge of role of } \\
\text { volunteers in potato virus transmission }\end{array}$ & 0.5 & 0.8 & 0.35 & & \\
\hline Using host resistance in virus control & & & & 0.2 & 0.0 \\
\hline Proportion of farmers selecting virus-resistant potato cultivars & 0.2 & 0.0 & 1.0 & & \\
\hline
\end{tabular}

* The criteria of virus control (in italics) and their corresponding indicators. Each indicator value represents the proportion of farmers having knowledge of or practise virus control under each of the listed categories

** Indicator values derived from proportion of farmers with knowledge in an aspect of virus control, e.g. a value of 1.1 means $11 \%$ of farmers had knowledge of a particular aspect of virus control

*** Indicator weights assigned based on expert knowledge and experience and outcomes of farmers surveys. Under each criterion, all the indicators added up to 1.0 and each of the indicators was given a value which ranged from 0 to 1 based on its relative potential to influence the overall outcome of virus control. The experts were scientists with experience in potato virus epidemiology in Kenya

**** Criteria values were calculated as the total sum of the products of the individual indicator values for each county and their respective indicator weights, e.g. a value of 2.3 under Vector transmission of viruses in Kiambu was calculated as $(2.4 \times 0.33)+(4.0 \times 0.33)+(0.5 \times 0.33)$ as proposed by Marinus et al. $(2018)$. The values range from 0 to 10 where ' 0 ' depicts an aspect of virus control that requires the highest priority in implementation of virus control while 10 , the least priority 


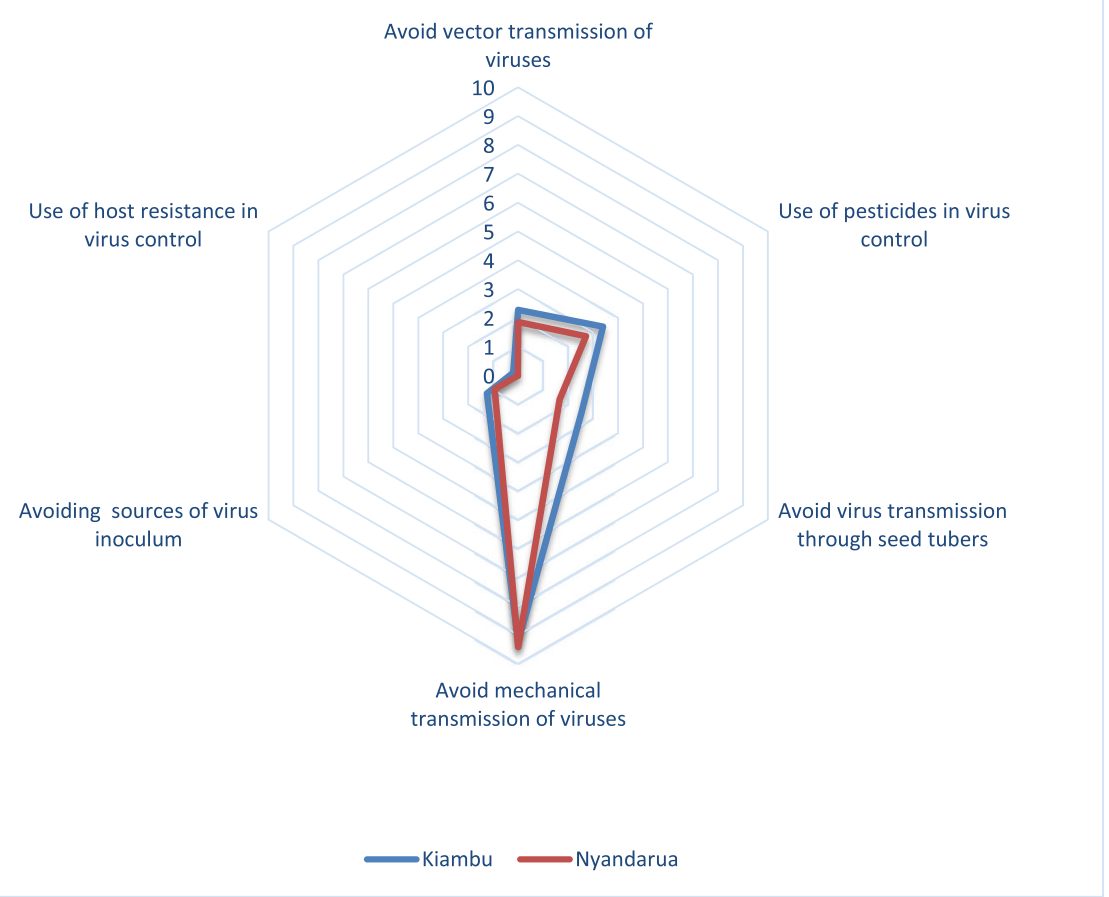

Fig. 5 Spider diagram showing criteria values of what the farmers are doing to control potato viruses in Kiambu and Nyandarua counties in Kenya

In both counties, the use of host resistance in virus control and avoiding sources of virus inoculum were the two aspects that had the lowest criteria values and thus require most urgent attention. Avoiding mechanical transmission of viruses with the highest criteria values of 9.2 and 9.4 in Kiambu and Nyandarua counties, respectively, was found to be of lowest priority in potato virus control. There were minor differences in criteria and indicator values between the two counties though this did not affect the order of priority ranking. The spider diagrams reflect slight differences in the specific knowledge needs of the two counties though these differences did not affect the order of ranking between the two counties.

\section{Discussions and Conclusions}

\section{A Description of Farmers' Knowledge and Practice in Potato Virus Epidemiology and Control}

\section{Farmer's Knowledge of Virus Symptoms and Vector Virus Transmission}

The concept of potato virus, virus symptoms and mode of transmission of viruses is not well understood by farmers in Kiambu and Nyandarua counties. Farmers were not able to 


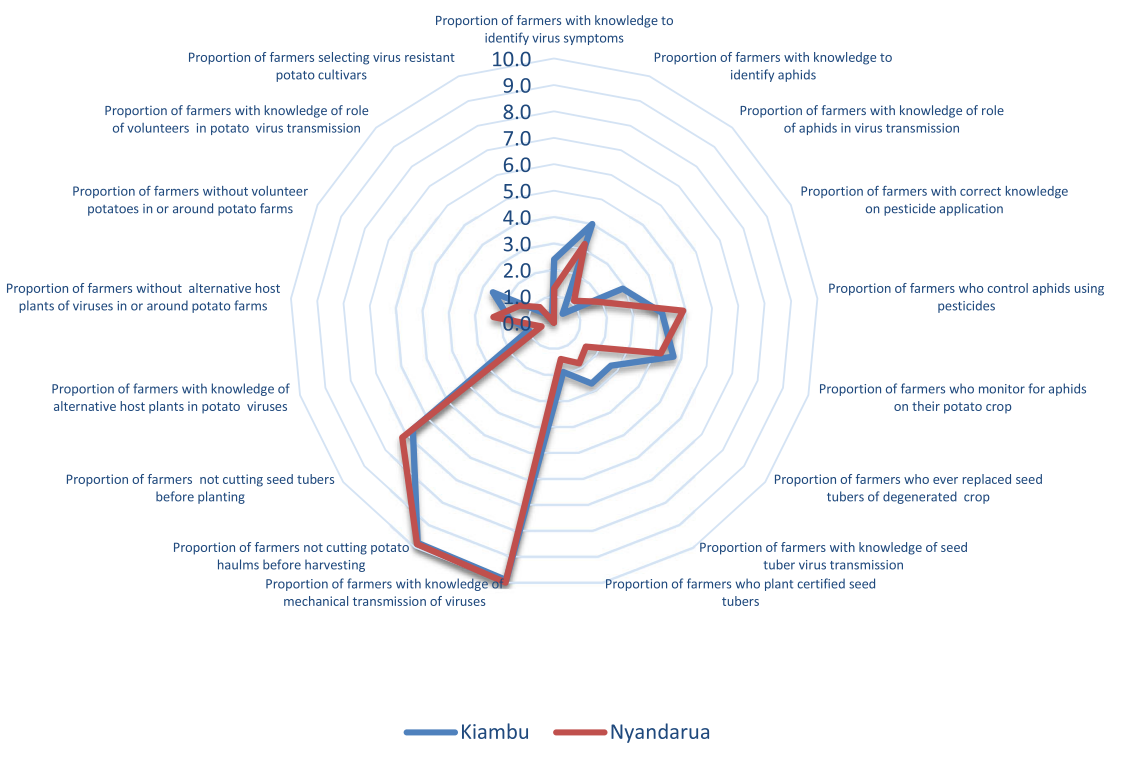

Fig. 6 Spider diagram showing indicator values (see Table 5) of what the farmers are doing to control potato viruses in Kiambu and Nyandarua counties in Kenya

clearly distinguish viruses as a separate biotic entity from other constraints to potato production. This is likely to have a negative impact on potato production because improving potato yields largely depends on control of potato viruses and their vectors (Syller 1996). Farmers need to have a basic knowledge and ability (Waqar 2017) to correctly identify virus diseases and the aphids which act as virus vectors. This lack of knowledge could be one of the reasons for the high virus prevalence reported in previous surveys (Gildemacher et al. 2009; Muthomi et al. 2009). Just like in this study, limited knowledge of plant viruses as opposed to other pathogens has been reported by other authors working on different crops elsewhere (Colvin et al. 2012; Adam et al. 2015). Virus symptoms have proved difficult to differentiate from other biotic and abiotic stresses on the crop, a fact that can be a major hindrance to virus management. Diagnosis of virus infection through observation of visual symptoms is a challenge to farmers because virus symptom expression in plants usually depends on the virus strains/types (García-Arenal et al. 2001) and multiple infections of the host with different viruses or pathogens, levels of host plant resistance and (changing) climatic conditions (Mendez-Lozano et al. 2003). Knowledge of virus symptoms can help farmers know when their crop is infected so that they can take appropriate actions like negative selection, positive selection (Priegnitz et al. 2019) or replace infected seed tubers with disease-free certified seed tubers among other methods.

\section{Use of Insecticides to Control Aphids}

Insufficient farmer knowledge in pesticide application to control aphids that transmit potato viruses as found in this study can hinder efforts to minimise potato virus transmission in potato fields. Application of pesticides without following action 
guidelines as found among Kenyan farmers may lead to development of resistance in aphid populations which may cause further outbreaks (Ragsdale et al. 2001). Farmers in such situations could be at a risk of exposure to hazardous chemicals with possibilities of environmental pollution (Islam et al. 2017) resulting in health risks and economic losses arising from ineffective control of pests and diseases (Rahman et al. 2013). In addition, weekly monitoring of aphids, or even at shorter interval (3-4 days), reduces exponential spread of viruses if aphids are controlled in time. Improving farmers' knowledge on safe and effective use of insecticides is therefore essential to reducing aphid populations which may cause virus transmission.

\section{Use of Host Resistance to Control Potato Viruses and Improve Potato Yields}

Farmers normally grow and maintain potato cultivars with traits they consider important in their cropping system (Crissman et al. 1993; Kaguongo et al. 2008). High yield is one of the most important traits that farmers consider in cultivar selections (Semagn et al. 2017) without knowing the underlying factors. In the Kenyan potato-growing situation with high potato virus prevalence and yield losses associated with virus infections (Muthomi et al. 2009; Were et al. 2013; Onditi et al. 2016), potato virus resistance is among the important traits associated with high potato yields (Onditi et al. 2013). Virus resistance is therefore among the main characteristics that farmers need to consider in selecting cultivars which can withstand yield and crop quality degeneration which occurs over seasons of replanting virus-infected seed tubers (Jayashige et al. 1989; Beukema and van der Zaag 1990; Hide and Lapwood 1992).

Average yields of $5.1 \mathrm{t} / \mathrm{ha}$ as found in this study are lower than the expected national average of $8.2 \mathrm{t} / \mathrm{ha}$ (FAOSTAT 2017). Average yields varied considerably between the counties and cultivars. For instance, in Nyandarua, only Shangi is grown and an average yield of 7.3 t/ha was reported. In Kiambu, $83.5 \%$ of farmers grew Shangi but an average yield of only 2.8 tha was reported for this cultivar. The other 10 cultivars grown in Kiambu varied in their reported yields but since they represent only a small fraction of all potatoes grown, their influence on the total average yield is limited. The lower yields reported in this study could be due to the errors by farmers in reporting or estimating the actual sizes of the area under potato production in their farms and also in estimating yield of potatoes harvested per unit area. Future surveys of this kind can be improved by conducting the survey during growing periods to measure the actual area under potato, estimate the crop spacing/population and also take measurements of weight of tubers at harvest.

Cultivars Shangi, Unica and Tigoni with higher yields than the overall average of 5.1 tha could be having higher levels of resistance to locally important seed-borne diseases including potato viruses. Since most farmers considered higher yields as the most important factor in potato cultivar choice and selection, selecting high yielding cultivars under high virus pressure could be an indirect way of selecting cultivars with tolerance to viruses (Cooper and Jones 1983; Valkonen et al. 1994).

\section{Virus Transmission Through Seed Tubers}

When farmers plant own farm saved seed tubers, which in many cases have significant amounts of virus infections, potato viruses are transmitted from one season to the next, 
especially in susceptible cultivars and sometimes with increased severity. This results in successive loss of yield and crop quality through a process called virus degeneration (Rahman et al. 2010). In this study, only $22.6 \%$ of the farmers were aware that planting tubers from sources whose health status is not known is a practice that could be contributing to the spread of potato viruses. In addition, only $21.0 \%$ of farmers were found to have previously replaced tubers of their degenerated potato crop with a newer healthier source of tubers for planting. These results demonstrate that the majority of farmers lack effective knowledge of the importance of 'seed health' as a major factor that determines success in potato production (Thomas-Sharma et al. 2016). Planting farmers' own saved ware tubers over several cropping generations could be leading to virus transmission and could be one of the factors contributing to the low national average potato yields of $8.2 \mathrm{t} / \mathrm{ha}$ (FAOSTAT 2017). As in previous studies, the use of own seed and seed from neighbours or from local markets is still a common practice not only among farmers in Kenya but also among farmers in neighbouring Uganda and Ethiopia (Gildemacher et al. 2009; Kaguongo et al. 2014; Priegnitz et al. 2019).

In Kenya, the ideal solution is to encourage farmers to plant certified seed tubers or seed tubers known to contain lower levels of seed-borne diseases (viruses) like positively selected or quality declared seed (Kaguongo et al. 2014). However, lack of sufficient quantities of certified seed tubers at affordable prices is one of the reasons that hinders efforts to use healthy seed tubers (Kaguongo et al. 2008). Formal sources of certified seed tubers can only satisfy 5\% of the national demand in Kenya (NPCK 2017). Improving availability of certified seed potato requires expansion of the current infrastructure for seed production and policy streamlining within the potato value chain. Since this is likely to take a longer duration of time, there is a need for short-term intervention strategies. Farmers have the alternative of improving the quality of their seed tubers by use of positive seed selection. This innovation has been practised with farmer groups and was found to improve potato tubers yields in Kenya (Gildemacher et al. 2011; Schulte-Geldermann et al. 2012; Onduru et al. 2019) and Uganda (Priegnitz et al. 2019). Training of farmers and farmer groups should go hand in hand with upscaling the use of positive selection to ensure that farmers are conversant with basic skills for selecting healthy looking plants. Farmers can also plant border crops around their potato farms to reduce vector populations and subsequent virus transmission to their crops (Muindi et al. 2009). In addition, there should be upscaling of some of the new methods of rapid mini-tuber production like aeroponics, hydroponics (Mbiyu et al. 2012) and potato apical stem-cutting technique (Carli et al. 1994) which have been found to increase the rate of seed production. Appropriate incentives need to be implemented to attract more private investors into potato seed production businesses. Importation of certified seed tubers from established potato seed and breeding companies in Europe has already been piloted over the past 10 years and has provided lessons on the regulatory and phytosanitary challenges that still need to be overcome to assure increased availability of certified seed tubers to farmers (NPCK 2017). Methods of monitoring and minimizing vector populations need to be developed/adopted locally to reduce virus transmission within the farmers' fields and also in the seed production sites.

\section{Mechanical Transmission of Potato Viruses}

Most potato viruses (except PLRV) can be transmitted mechanically through contact with plant sap or tissue that is infected with viruses during farm operations like cutting 
tubers before planting and cutting haulms before harvesting (Woodford 1992). In the Kenyan situation, there was an indication that spread of potato viruses based on practices that cause mechanical transmission of viruses was of minimal impact because farmers did not follow practices that favour virus transmission in this manner.

\section{Role of Alternative Host Plants and Other Sources of Virus Inoculum for Virus Transmission}

Abundance of sources of virus inoculum (virus infected plants) as reported in this study coupled with high incidence of virus vectors and alternative virus host plants around potato fields can aid spread of aphid borne potato viruses. In this study, only $10.7 \%$ of farmers knew about the potential threat of alternative host plants of viruses in their potato farms. Plant species belonging to the same family as potato (Solanaceae) or other families like Asteraceae, Brassicaceae, Chenopodiaceae, Commelinaceae and Fabaceae can act as potential alternative host plants for viruses around the potato farms and increase chances of virus transmission to potato fields. Alternative virus host plants (weeds and crops) which grow for longer periods on the farm can increase chances of virus transmission from one cropping season to the next when these periods overlap with the next potato season, because most farmers grow potatoes more than once a year. Farmers can avoid virus transmission from infected plants by using a crop rotation plan whereby a host plant of a potato virus does not precede a potato crop during the subsequent seasons of rotation (Thresh 1982). Similarly, the potential host plants of viruses should not be intercropped with a potato plant to avoid virus transmissions (Duffus 1971). However, the low numbers of farmers practising this as found in this study is an indication that virus spread through improper practice of crop rotation and intercropping is likely to be low.

Farmers' practice of maintaining volunteers in Kiambu and Nyandarua regions of Kenya can make it difficult to eliminate viruses from the crop especially if cultivars grown by farmers are susceptible to viruses (Wright and Bishop 1981; Koepke-Hill et al. 2010). Even if farmers plant certified seed tubers with low virus loads, these would after a short while succumb to the high virus pressure on farms and force farmers to replace seed tubers.

Overlapping cropping periods could allow crops in neighbouring farms to maintain aphids and allow for vector migration and virus transmission considering the high prevalence of potato viruses in the region. When there is a potato crop in the farm or in neighbouring farms all year round, the crop can maintain aphid species that could play an important role in virus transmission (DiFonzo et al. 1994). Survival of such aphid species depends upon suitable host plants some of which are potato crops in neighbouring fields. In such farming systems, virus control can be a challenge due to proximity to a constant source of virus inoculum.

\section{Analysis of Order of Priority in Intervention in Potato Virus Control Using Spider Diagrams}

The main aim of using a spider diagram approach was to provide a platform for ranking various methods of virus control and to help in decision making on the most preferable or applicable method to use for potato virus control in Kenya. This is because not all 
virus control methods have the same magnitude of impact when deployed and success of their applicability may differ from one region to another. There are often variations in level of farmer knowledge and farming practices making one blanket virus control strategy unreasonable (Priegnitz et al. 2019). Sometimes, it is impractical to apply all the different virus control methods at the same time due to scarcity of resources.

In this study, we used two parameters, namely (a) the existing level of farmer knowledge/practice in potato virus control as derived from the farmer household survey and (b) the experts' opinions on the potential relative impact of each of the indicators of potato virus epidemiology and control to determine the final outcome of the platform for decision making in potato virus control in Kenya. The use of farmer knowledge and experiences has previously been reported to be effective in setting up a control strategy for pest and disease problems in farming systems (Florin et al. 2012; Mendesil et al. 2016; Midega et al. 2016). The existing level of farmer knowledge is essential in decision making because it gives an idea of the specific aspects of virus control which farmers already know about and which they do not know so that more focus is given to areas in which farmers have limited knowledge. For instance, in Table 5, indicator values of 9.9 and 10.0 (in Kiambu and Nyandarua, respectively) for the proportion of farmers with knowledge of mechanical transmission of viruses are an example of an aspect of virus control that does not require much attention. On the other hand, values of 0.2 and 0.0, respectively, indicate that farmers have limited knowledge of virusresistant potato cultivars and this requires more attention in intervention in virus control. The experts' opinions were used to give different weights to the different indicators under each criterion because it is important to understand available and practical options for virus control as well as their potential influence in the overall virus control in the farmers' fields.

Experts' opinion scores on various indicators of virus control were based on a consensus after deliberations on their personal experiences in potato research in Kenya and also on the available literature, as determined by the relative impact of each of the indicators on potato virus epidemiology and control and in relation to the potatoproducing situation in the country. Based on scientific reasoning, assignment of the individual weight factors among the different experts was quite unanimous but obviously these factors can always be a matter of debate. Varying the weights of the different indicators under each criterion however had only a marginal effect on the overall outcome of the relative importance of the six criteria and the overall shapes of the spider diagrams. Increasing the weight factor of farmer knowledge on virus symptoms from 0.33 to 0.5 while decreasing the weight factor on their knowledge of aphids to 0.2 only changed the criterion value for vector transmission of viruses from 2.3 to 2.6 in Kiambu. Changing the weights for the four indicators for avoiding sources of virus inoculum to respectively $0.10 / 0.10 / 0.50 / 0.30$ changed the values for this criterion only from 1.3 to 1.7 for Kiambu and from 1.1 to 1.2 for Nyandarua. The relatively low values of the indicators (see Table 5) show that most farmers had generally little knowledge of the role of the criteria and their underlying indicators in the control of potato viruses with the only exception being the mechanical transmission of viruses. Most farmers were aware that cutting seed potatoes spreads diseases and few farmers cut haulms.

The success of potato virus control will largely depend on the depth of farmers' understanding of not just virus control but also virus epidemiology within their context 
of potato farming. Under the criterion on vector transmission of viruses, all the three indicators were allocated equal weights of 0.33 each because all of them involved enhancing farmer knowledge. In the rest of the criteria, the indicators involving enhancing farmer knowledge were given higher relative weights than those that involved farmer practice. For instance, the indicator 'proportion of farmers with correct knowledge on pesticide application' under the criterion using pesticides in virus vector control was given a higher weight of 0.67 as compared to 0.17 each for the rest of the indicators under the criterion.

Final ranking of the different criteria (Fig. 5) as calculated from the individual indicator values and indicator weights identified the using host resistance in virus control with the lowest values of 0.2 and 0.0 in Kiambu and Nyandarua, respectively, an indication that it should be the most preferred method of potato virus control in Kenya. This is supported by the fact that virus-resistant cultivars often have minimal virus prevalence and can be replanted for several seasons with minimal yield reductions arising from virus infections (Thomas-Sharma et al. 2016). Thus, in Kenya where there is limited supply of healthy seed tubers (NPCK 2017) and the majority of farmers are forced to plant their own saved ware potato tubers over several seasons (Gildemacher et al. 2009), planting virus-resistant cultivars is likely to lower yield losses. Utilization of host resistance to potato viruses in Kenya can be implemented by breeding potato cultivars with resistance to the locally important viruses and availing such virusresistant cultivars to the farmers. Since potato cultivar development usually takes a long time (5-10 years) and farmers may be in need of an immediate solution, it is also important to identify virus-resistant cultivars especially among those already being grown in the farmer's fields to enhance cultivar adoption and immediate utilization by the farmers.

The criteria on avoiding sources of virus inoculum came second in the order of priority, also with low values (Fig. 5) of 1.1 and 0.9 in Kiambu and Nyandarua, respectively. This aspect of virus control came second because the survey already indicated that farmers in the two counties have limited knowledge of the potential role of alternative host plants and potato volunteers in potato virus transmission. Farmers can be advised to remove alternative host plants of potato viruses which occur as weeds within their farms and also volunteer potatoes that occur after harvest of potato crops to reduce their chances of acting as sources of inoculum for potato virus transmission. It would also be advisable for the farmers to implement a crop rotation plan where potato crop is only followed by non-Solanaceous crops like maize, beans and cabbage which the farmers already grow in the region. Implementation of removal of sources of virus inoculum around potato farms can however be a challenge if it is not applied uniformly by all the farmers across a particular region. In addition, effective vector control should not just focus within the farm but also in the bushes around the farms. This is because of the migratory behaviour of the aphids which act as vectors of the viruses (Ragsdale et al. 2001), and therefore removal of a host in one farm may lead to movement of the vector to a different farm where alternative host of viruses is not controlled. This aspect of virus control is of priority because it is challenging and will require more effort to implement.

The third most important criterion was virus transmission through seed tubers with final values of 2.5 and 1.7 in Kiambu and Nyandaraua, respectively. Reducing virus transmission through seed tubers is a priority in Kenya because only a small proportion 
of farmers $(5 \%)$ have access to certified seed tubers. For over a decade now, the majority of the farmers in Kenya have been planting their own saved ware potato tubers or tubers from sources whose health status is not ascertained (Gildemacher et al. 2009; Kaguongo et al. 2014). This criterion is of importance because all the six major potato viruses (PLRV, PVY, PVX, PVM, PVS and PVA) in the region are transmitted through infected tubers from one cropping season to another. Success of potato farming will largely depend on reducing chances of virus transmission through seed tubers and improving seed health. The ideal solution is to produce and distribute certified seed tubers to the farmers. This however may take a longer duration of time because it will require improvement of existing infrastructure for seed production, stakeholder involvement along the potato value chain and potato seed policy streamlining to fit the potato-growing situation in Kenya. This survey indicated that farmers have limited knowledge of virus transmission through seed tubers, hence improving farmer knowledge on the alternative methods of improving seed health/quality within their farms like positive selection should be explored.

The criterion on vector transmission of viruses was ranked fourth with relative lower final criteria values 2.3 and 1.9 in Kiambu and Nyandarua, respectively. The low values resulted from the low proportion of farmers with limited knowledge and ability to identify symptoms, aphids and virus transmission. Training farmers on the virus symptoms and on how to monitor and identify aphids and to understand the role of aphids in virus transmission will be vital in virus control in farmers' fields.

The fifth-ranking criterion was on using pesticides in virus vector control with final criteria values of 3.4 and 2.7 in Kiambu and Nyandarua, respectively. This criterion was not of very high priority because almost a half of the farmers were already using pesticides for controlling aphids. For success of virus control, farmers therefore need to train on safe and effective use of pesticides. Without this, success of this method of virus control can be a challenge because pesticide application always has to be done correctly across all the small-scale farms in a particular region (in Kenya). Improper application of pesticides can pose a health risk to humans and to the environment and can also lead to pesticide resistance in the aphids limiting chances of its success of virus control. The least-ranking criterion was on mechanical transmission of viruses. This was influenced by the fact that the majority of farmers were already aware that the viruses in their farms can be mechanically transmitted if they engage in practices such as cutting tubers without disinfection or cutting of stems at harvesting.

This study emphasises the importance of comparing and ranking different methods of virus control prior to their application in the farmers' fields. Policymakers can subsequently focus on specific regions with a specific lack of knowledge to cut cost of intervention logistics in virus control. We found that the use of host resistance will be of much more benefit than other methods of virus control. This however does not mean that the rest of the virus control methods should be ignored. Some methods that fell into the second-, third- and fourth-ranking criteria equally had low final values indicating that they also need attention. With this knowledge, virus control in Kenya can now focus in coming up with a tailor-made curriculum for virus control which can be used for training by the agricultural extension officers and other stakeholders in the potato industry. 
Acknowledgements We are very grateful to the farmers in Nyandarua and Kiambu counties in Kenya for providing information willingly and being a valuable asset to us during data collection. Similarly, we thank the agricultural officers in the two counties and data enumerators who helped us to co-ordinate the data collection process. Finally, we thank the Kenya Agricultural and Livestock Research Organization (KALRO), Kenya and Wageningen University and Research (WUR), The Netherlands, for supporting this study.

Open Access This article is licensed under a Creative Commons Attribution 4.0 International License, which permits use, sharing, adaptation, distribution and reproduction in any medium or format, as long as you give appropriate credit to the original author(s) and the source, provide a link to the Creative Commons licence, and indicate if changes were made. The images or other third party material in this article are included in the article's Creative Commons licence, unless indicated otherwise in a credit line to the material. If material is not included in the article's Creative Commons licence and your intended use is not permitted by statutory regulation or exceeds the permitted use, you will need to obtain permission directly from the copyright holder. To view a copy of this licence, visit http://creativecommons.org/licenses/by/4.0/.

\section{References}

Adam RI, Sindi K, Badstue L (2015) Farmers' knowledge, perceptions and management of diseases affecting sweet potatoes in the Lake Victoria zone region, Tanzania. Crop Prot 72:97-107. https://doi.org/10.1016/ j.cropro.2015.02.010

Almekinders CJM, Walsh S, Jacobsen KS, Andrade-Piedra JL, McEwan MA, de Haan S, Kumar L, Staver C (2019) Why interventions in the seed systems of roots, tubers and bananas crops do not reach their full potential. Food Sec 11:23-42. https://doi.org/10.1007/s12571-018-0874-4

Beemster ABR, de Bokx JA (1987) Viruses, viroids, mycoplasmas and diseases with a virus-like aetiology. Survey of properties and symptoms. In: de Bokx JA, van der Want JRH (eds) Viruses of potatoes and seed-potato production Second Edition. PUDOC, Wageningen, pp 233-245

Beukema HP, van der Zaag DE (1990) Introduction to potato production. PUDOC, Wageningen

Carli C, Njoroge PK, Makwa CM (1994) Seed potato (Solanum spp.) production using apical cuttings and tubercles in Kenya. Acta Hortic 380:513-513

Chandla VK, Shiv K, Sighn MN, Verma KD, Paul Khurana SM (2001) Role of aphids in degeneration of seed stocks in the higher hills. Ind Pot Ass 28(1):117-118

Colvin J, Nagaraju N, Moreno-Leguizamon C, Govindappa RM, Reddy TBM, Padmaja SA, Joshi N, Hanson PM, Seal SE, Muniyappa V (2012) Socioeconomic and scientific impact created by whitefly-transmitted, plant-virus disease resistant tomato varieties in southern India. J Integr Agric 11(2):337-345. https://doi. org/10.1016/S2095-3119(12)60018-5

Cooper JI, Jones AT (1983) Responses of plants to viruses, proposals for the use of terms. Phytopathology 73 : $127-128$

Crissman CC, Crissman LM, Carli C (1993) Seed potato systems in Kenya: a case study. International Potato Centre, Lima

De Olde EM, Oudshoorn FW, Sorensen CAG, Bokkers EAM, De Boer IJM (2016) Assessing sustainability at farm-level: lessons learned from a comparison of tools in practice. Ecol Indic 66:391-404. https://doi.org/ 10.1016/j.ecolind.2016.01.047

DiFonzo CD, Ragsdale DW, Radcliffe EB (1994) Potato leaf roll virus spread in differentially resistant potato cultivars under varying aphid densities. Am Potato J 72:119-132

Duffus JE (1971) Role of weeds in the incidence of virus diseases. Annu Rev Phytopathol 9:313-340

Fageria M, Nie X, Gallagher A, Singh M (2015) Mechanical transmission of potato virus Y (PVY) through seed cutting and plant wounding. Am Potato J 92(1):143-147. https://doi.org/10.1007/s12230-014-9418-4

FAOSTAT (2017) FAOSTAT. Commodities by country, Kenya, potatoes, 2017. http://www.fao.org/faostat/ en/\#rankings/commodities_by_country. Accessed in Aug 2019

Florin MJ, van Ittersum MK, van de Ven GWJ (2012) Selecting the sharpest tools to explore the food-feedfuel debate: sustainability assessment of family farmers producing food, feed and fuel in Brazil. Ecol Indic 20:108-120. https://doi.org/10.1016/j.ecolind.2012.02.016

Florin MJ, van de Ven GWJ, van Ittersum MK (2014) What drives sustainable biofuels? A review of indicator assessments of biofuel production systems involving smallholder farmers. Environ Sci Policy 37:142157. https://doi.org/10.1016/j.envsci.2013.09.012 
García-Arenal F, Fraile A, Malpica JM (2001) Variability and genetic structure of plant virus populations. An Rev Phytopathol 39(1):157-186. https://doi.org/10.1146/annurev.phyto.39.1.157

Gildemacher PR, Demo P, Barker I, Kaguongo W, Woldegiorgis G, Wagoire WW, Wakahiu M, Leeuwis C, Struik PC (2009) A description of seed potato systems in Kenya, Uganda and Ethiopia. Am J Potato Res 86(5):373-382

Gildemacher PR, Schulte-Geldermann E, Borus D, Demo P, Kinyae P, Mundia P, Struik PC (2011) Seed potato quality improvement through positive selection by smallholder farmers in Kenya. Potato Res 54(3):253-266. https://doi.org/10.1007/s11540-011-9190-5

Hide GA, Lapwood DH (1992) Disease aspects of potato production. In: Harris P (ed) The potato crop. The scientific basis of potato improvement, 2nd edn, pp 403-437. https://doi.org/10.1007/978-94-011-2340-2

Islam WJ, Zhang M, Adnan A, Noman M, Zaynab M, Wu Z (2017) Plant virus ecology: a glimpse of recent accomplishments. Appl Ecol Environ Res 15(1):691-705. https://doi.org/10.15666/aeer/1501_691705

Janssens SRM, Wiersema SG, Goos H, Wiersema W (2013) The value chain for seed and ware potatoes in Kenya; opportunities for development. LEI Memorandum 13-080, Wageningen

Jayashige U, Chuquilllanqui C, Salazar LF (1989) Modified expression of virus resistance in potato in mixed virus infections. Am Potato J 66(3):137-144. https://doi.org/10.1007/BF02853674

Jones AC, Woodford JAT, Main SC, Pallett D, Barker H (1996) The role of volunteer potatoes in the spread of potato virus $\mathrm{Y}^{\mathrm{N}}$ in ware crops of cv. Record. Ann Appl Biol 129:471-498. https://doi.org/10.1111/j.17447348.1996.tb05769.x

Kabira JN, Wakahiu M, Wagoire W, Gildemacher P, Lemaga B (2006) Guidelines for production of healthy seed potatoes in East and Central Africa. Kenya Agricultural Research Institute, Nairobi

Kaguongo WP, Gildemacher P, Demo P, Wagoire W, Kinyae P, Andrade J, Forbes G, Fuglie K, Thiele G (2008) Farmer practices and adoption of improved potato varieties in Kenya and Uganda. International Potato Centre (CIP), Lima, Peru

Kaguongo W, Maingi G, Barker I, Nganga N, Guenthneret J (2014) The value of seed potatoes from four systems in Kenya. Am J Potato Res 91:109-118. https://doi.org/10.1007/s12230-013-9342-Z

Khurana SMP, Pandey SK, Bhale U, Patel RL, Lakra BS (1998) Degeneration of potato varieties in northern and central India. Indian J Virol 14(21):111-119

Koepke-Hill R, Armel G, Wilson H, Hines T, Vargas J (2010) Herbicide combinations for control of volunteer potato. Weed Technol 24(2):91-94. https://doi.org/10.1614/WT-D-09-00017

Lung'aho C, Nderitu SKN, Kabira JN, El-Bedewy R, Olanya OM, Walingo A (2006) Yield performance and release of four late blight tolerant potato varieties in Kenya. J Agron 5:57-61. https://doi.org/10.3923/ja. 2006.57.61

Machangi JM (2003) Occurrence of viruses and aphid vectors in small-scale potato seed production systems and their effect on yield in Kenya, MSc thesis University of Nairobi, Kenya

Maduka O, Akpan G, Maleghemi S (2017) Using Android and open data kit technology in data management for research in resource-limited settings in the Niger Delta Region of Nigeria: cross-sectional household survey. JMIR Mhealth Uhealth 5(11):171. https://doi.org/10.2196/mhealth.7827

Marinus W, Ronner E, Ven GWJ, Kanampiu F, Adjei-Nsiah S, Giller KE (2018) The devil is in the detail!: sustainability assessment of African smallholder farming. In: Bell S, Morse S, Routledge P (eds) Routledge Handbook of Sustainability Indicators, pp 427-450. https://doi.org/10.4324/9781315561103-28

Mbiyu MW, Muthoni J, Kabira J, Elmar Muchira C, Pwaipwai P, Ngaruiya J, Otieno S, Onditi J (2012) Use of aeroponics technique for potato (Solanum tuberosum) mini tubers production in Kenya. J Hort For 4:172177

Mendesil E, Shumeta Z, Anderson P, Ramert B (2016) Smallholder farmers' knowledge, perceptions and management of pea weevil in north and north-western Ethiopia. Crop Prot 81:30-37. https://doi.org/10. 1016/j.cropro.2015.12.001

Mendez-Lozano J, Torres-Pacheco I, Fauquet CM, Rivera-Bustamante RF (2003) Interactions between Geminiviruses in a naturally occurring mixture: pepper huasteco virus and pepper golden mosaic virus. Phytopathology 93(3):270-277. https://doi.org/10.1094/PHYTO.2003.93.3.270

Midega CAO, Murage AW, Pittchar JO, Khan ZR (2016) Managing storage pests of maize: Farmers' knowledge, perceptions and practices in western Kenya. Crop Prot 90:142-149. https://doi.org/10. 1016/j.cropro.2016.08.033

Muindi EM, Muthomi JW, Nderity JH, Olubayo FM, Kabira JN, Chemining'wa GN, Kiretai SM, Aura JA (2009) Use of cereal border crops in management of aphid-transmitted viral diseases during seed potato (Solanum tuberosum) production. Afr J Hort Sci 2:69-78

Muthomi JW, Nyaga JN, Olubayo FM, Nderitu JH, Kabira JN, Kiretai SM, Aura JA, Wakahiu M (2009) Incidence of aphid transmitted viruses in farmer-based seed potato production in Kenya. Asian J Plant Sci 8(2):166-171. https://doi.org/10.3923/ajps.2009.166.171 
NPCK (2017) Potato variety catalogue. National Potato Council of Kenya, Nairobi, Kenya. Available online: http://npck.org/Catalogues/NPCK\%20CATALOGUE\%202017\%20booklet\%20K2.pdf. Accessed in Nov 2019

ODK (2018) Open Data Kit. Available: http://opendatakit.org/. Accessed: 2018 Jul 20

Olubayo F, Kibaru J, Nderitu J, Njeru R, Kasina M (2010) Management of aphids and their vectored diseases on seed potatoes in Kenya using synthetic insecticides, mineral oil and plant extract. J Innova Dev Strateg $4(2): 1-5$

Onditi JO, Nderitu SWK, Landeo JA, Abong' GO, Sikinyi EO, Kabira JN (2012) Release of three improved varieties for the expanded potato market in Kenya. Agric Biol J N Am 3(5):192-197. https://doi.org/10. 5251/abjna.2012.3.5.192.197

Onditi J, Njoroge K, Shibairo S (2013) Improving potato tuber yields using genotypes with multiple virus resistance in Kenya. Agric Biol J N Am 4(4):406-441. https://doi.org/10.5251/abjna.2013.4.4.406.412

Onditi OJ, van der Vlugt RA, Nyongesa M (2016) Occurrence of potato virus Y (PVY) in major potato cultivars in Kenya. International Phytosanitary Conference, 12th to $16^{\text {th }}$ September 2016, KEPHIS Headquarters, Karen, Nairobi

Onduru OG, Naria RD, Otieno HMO, Schulte-Geldermann E (2019) Response of selected potato genotypes to natural virus infections in the field. Asian J Crop Sci 3:1-13

Priegnitz U, Lommen WJM, van der Vlugt RAA, Struik PC (2019) Impact of positive selection on incidence of different viruses during multiple generations of potato seed tubers in Uganda. Potato Res 62(1):1-30. https://oi.org/10.1007/s11540-018-9394-z

QGIS (2019) QGIS, A Free and Open Source Geographic Information System. https://qgis.org/en/site/. Accessed Jan 2019

Ragsdale DW, Radcliffe EB, DiFonzo CD (2001) Epidemiology and field control of PVY and PLRV. In: Loebenstein G, Berger PH, Brunt AA, Lawson RH (eds) Virus and virus-like diseases of potatoes and production of seed-potatoes. Kluwer Academic Publishers, Dordrecht, pp 237-270. https://doi.org/10. 1007/978-94-007-0842-6

Rahman MS, Akanda AM, Mian IH, Bhuian MKA, Karim MR (2010) Growth and yield performance of different generations of seed potato as affected by PVY and PLRV. Bangladesh J Agric Res 35(1):37-50. https://doi.org/10.3329/bjar.v35i1.5865

Rahman AS, Mehboob W, Khan NA (2013) Reaction of gram (Cicer Arietinum L.) varieties against gram blight disease (Didymella Rabiei (Kovatsch.) Arx) and its management through foliar fungicides in rainfed areas of Pakistan. Pak J Phytopathol 25(01):07-14

Salazar L F (1996) Potato viruses and their control. International Potato Centre, Lima

Schulte-Geldermann E, Gildemacher PR, Struik PC (2012) Improving seed health and seed performance by positive selection in three Kenyan potato varieties. Am J Potato Res 89:429. https://doi.org/10.1007/ s12230-012-9264-1

Semagn AK, De Jong W, Perry K, Halseth D, Mengistu F (2017) Participatory variety selection: a tool to understand farmers' potato variety selection criteria. Open Agric 2:453-463. https://doi.org/10.1515/ opag-2017-0049

Singh AS, Masuku MB (2014) Sampling techniques \& determination of sample size in applied statistics research: an overview. Int J Econ Commer Manag 2(11):23

Struik PC, Kuyper TW, Brussaard L, Leeuwis C (2014) Deconstructing and unpacking scientific controversies in intensification and sustainability: why the tensions in concepts and values? Curr Opin Environ Sustain 8:80-88. https://doi.org/10.1016/j.cosust.2014.10.002

Syller J (1996) Potato leaf-roll virus (PLRV): its transmission. Integr Pest Manag Rev 1:217-227. https://doi. org/10.1007/BF00139765

Syller, Kaliciak A (2009) New hosts of potato virus Y (PVY) among common wild plants in Europe. Eur J Plant Pathol 124(4):707-713. https://doi.org/10.1007/s10658-009-9452-0

Thomas-Sharma S, Abdurahman A, Ali S, Andrade-Piedra JL, Bao S, Charkowski AO, Crook D, Kadian M, Kromann P, Struik PC, Torrance L, Garrett KA, Forbes GA (2016) Seed tuber degeneration in potato: the need for a new research and development paradigm to mitigate the problem in developing countries. Plant Pathol 65:3-16. https://doi.org/10.1111/ppa.12439

Thresh JM (1982) Cropping practices and virus spread. Annu Rev Phytopathol 20:193-218. https://doi.org/10. 1146/annurev.py.20.090182.001205

Valkonen JPT, Jones RAC, Slack SA, Watanabe KN (1994) Resistance specificities to virus in potato, standardization of nomenclature. Plant Breed 115:433-438. https://doi.org/10.1111/j.1439-0523.1996. tb00952.x

Waqar I (2017) Management of plant virus diseases; farmer's knowledge and our suggestions. Hosts Viruses 4(2):28-33. https://doi.org/10.17582/journal.bjv/2017/4.2.28.33 
Were HK, Kabira JN, Kinyua ZM, Olubayo FM, Karinga JK, Aura J, Lees AK, Cowan GH, Torrance L (2013) Occurrence and distribution of potato pests and diseases in Kenya. Potato Res 123:12-25. https:// doi.org/10.1007/s11540-013-9246-9

Woodford JAT (1992) Virus transmission by aphids in potato crops. Neth J Plant Pathol 98(2):47-54. https:// doi.org/10.1007/BF01974471

Wright GC, Bishop GW (1981) Volunteer potatoes as a source of potato leaf roll virus and potato virus X. Am J Potato Res 58(11):603-609. https://doi.org/10.1007/BF02853471

Publisher's Note Springer Nature remains neutral with regard to jurisdictional claims in published maps and institutional affiliations. 